\title{
Probabilistic assessment of geothermal resources and their development in Dikili-İzmir region
}

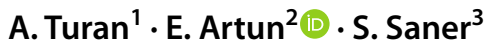

Received: 13 August 2020 / Accepted: 21 April 2021

Published online: 17 May 2021

(c) The Author(s) 2021 OPEN

\begin{abstract}
Dikili-Izmir Region (Western Turkey) has been an active area of development for the utilization of geothermal resources. In this study, we aim to quantify the untapped resource-potential in this region for both direct and indirect utilization purposes. After collecting geological data from the literature, probabilistic heat-in-place calculations are carried out. Yuntdağ Volcanites and Kozak Pluton are considered, and the latter is proposed as an enhanced geothermal system. It is shown that, with $50 \%$ probability, $75 \mathrm{MW}_{e}$ and $17 \mathrm{MW}_{e}$ of net electrical power can be produced from Yuntdağ and Kozak reservoir systems, respectively. When the unit volumes of reservoirs are considered, Kozak can produce 3.2 and 2.5 times of what Yuntdağ can produce in terms of electrical and thermal power, respectively. A sensitivity analysis is performed to understand the impact of reservoir characteristics on the reserves. Within the uncertainty ranges defined, reservoir size, temperature and recovery factor are found to be critical parameters that affect the net power output. Sustainability attributes are evaluated from both economic and environmental perspectives and potential benefits are discussed.
\end{abstract}

Keywords Geothermal · Enhanced geothermal systems $\cdot$ Resource assessment $\cdot$ Dikili $\cdot$ Western Turkey

\begin{tabular}{ll}
\multicolumn{2}{l}{ List of symbols } \\
$A$ & Area $\left(\mathrm{m}^{2}\right)$ \\
$C$ & Specific heat capacity $\left(\mathrm{kJ} / \mathrm{kg}^{\circ} \mathrm{C}\right)$ \\
$C F$ & Conversion factor (fraction) \\
$h$ & Thickness (m) \\
$L F$ & Load factor (fraction) \\
$N E P$ & Net electric power $\left(\mathrm{MW}_{e}\right)$ \\
$N T P$ & Net thermal power $\left(\mathrm{MW}_{t}\right)$ \\
$Q$ & Heat content $(\mathrm{J})$ \\
$Q_{t}$ & Total heat content $(\mathrm{kJ})$ \\
$Q_{s}$ & Heat content of the solid part $(\mathrm{kJ})$ \\
$Q_{w}$ & Heat content of the water part $(\mathrm{kJ})$ \\
$R F$ & Recovery factor (fraction) \\
$R H E$ & Recoverable heat energy (MW) \\
$t$ & Project life (seconds)
\end{tabular}

$T \quad$ Temperature $\left({ }^{\circ} \mathrm{C}\right)$

$T_{u} \quad$ Utilization temperature $\left({ }^{\circ} \mathrm{C}\right)$

$T_{r} \quad$ Reservoir (rock and fluid) temperature $\left({ }^{\circ} \mathrm{C}\right.$ )

$\rho \quad$ Density $\left(\mathrm{kg} / \mathrm{m}^{3}\right)$

$\phi \quad$ Porosity (fraction)

\section{Introduction}

A strong dependency on imported fossil fuels, environmental concerns and increasing energy demand due to economic growth in recent years require Turkey, as in many other countries, to consider better, cleaner and more sustainable ways of energy supply. A major energyefficiency program has been initiated with the goal of

E. Artun, artun@itu.edu.tr; A.Turan, turan@geo.tu-darmstadt.de; S. Saner, salih.saner@neu.edu.tr| 'Group of Geothermal Science and Technology, Institute of Applied Geosciences, Technische Universität Darmstadt, Schnittspahnstrasse 9, 64287 Darmstadt, Germany. ${ }^{2}$ Department of Petroleum and Natural Gas Engineering, Istanbul Technical University, 34469 Maslak, Istanbul, Turkey. ${ }^{3}$ Department of Petroleum and Natural Gas Engineering, Near East University, 99138 Mersin 10, Turkey. 
increasing the clean energy share at least to $30 \%$, while decreasing the share of natural gas in power supply to $30 \%$ [14]. One sustainable way to increase the clean energy share in the power generation can be the utilization of geothermal resources as they are abundant, reliable, domestic and able to provide base load. In 2014, the target for the installed capacity of geothermal resources was stated as $1000 \mathrm{MW}_{e}$ in the National Renewable Energy Action Plan of Turkey for the year 2023 [24] whereas this target was reached by 2017 [22]. As of today, the installed capacity of geothermal resources in Turkey is $1638 \mathrm{MW}_{e}$ [22] and the new target is $4000 \mathrm{MW}_{e}$ of installed capacity to be reached by 2030 [24].

In 2013, $93 \%$ of the total net electrical power was supplied by fossil fuels in Izmir, Turkey, a major city in Western Turkey. Wind was the only renewable source contributing to the electricity production with a share of 7\% [18]. The electricity consumption was $17.7 \times 10^{6} \mathrm{MWh}$, which corresponded to $7.2 \%$ of Turkey's total consumption. Electricity consumption per person was 4,348 kWh, 35.8\% more than Turkey's average, which may be attributed to relatively higher amount of cooling needs. İzmir hosts several geothermal sites with a temperature range changing from 153 to $130^{\circ} \mathrm{C}$ i.e. Balçova $136^{\circ} \mathrm{C}$, Dikili $130^{\circ} \mathrm{C}$, SeferihisarCumalı $153^{\circ} \mathrm{C}$ and Seferihisar-Akyar $153^{\circ} \mathrm{C}$ [30]. Until 2020,59\% of the geothermal resources in Izmir were being used for district heating, $36 \%$ for greenhouse heating and 5\% for thermal tourism [4]. As of October 2020, the first geothermal power plant of Izmir; RSC Seferihisar Geothermal Power Plant, with an installed capacity of 12 $\mathrm{MW}_{e}$, started to produce electricity [22]. Although geothermal energy is preferred over other intermittent renewable energy resources such as wind and solar as it requires no storage system and is capable of supplying baseload; in İzmir, among the 84 power plants, 30 of them are solar power plants, 35 of them are wind power plants while only 1 of them is a geothermal power plant [15] Therefore, considering Turkey's goals related to energy production, re-distribution of energy sources in the region to include cleaner and more renewable ones can be helpful.

In this study, it is aimed to investigate the potential of geothermal resources in Dikili-Izmir region in Western Turkey. Four scenarios are considered including direct and indirect utilization of Yuntdağ Volcanites, as a hydrothermal geothermal system, and Kozak Pluton, as an enhanced geothermal system (EGS). After researching the literature and collecting available data, resource assessment calculations and sensitivity analysis of input parameters are carried out. Sustainability attributes in terms of carbon emissions and economic aspects are also analyzed. For geothermal resource assessment, volumetric method [31] is applied to calculate thermal energy content and to estimate how much of this energy is recoverable to generate electric and thermal power. A probabilistic study, Monte Carlo simulation, is carried out to account for the uncertainties associated with reservoir characteristics. Similar resource assessment studies employing the volumetric method, were conducted for Balıkesir-Edremit geothermal site [7], for İzmir-Balçova [5], for Manisa-Alaşehir [1], and for Turkey [26]. In some cases, volumetric assessment can be combined with geophysical data to improve the assessment [41]. None of these earlier geothermal resource assessment studies highlights the sustainability attributes of the discussed geothermal systems. The present study analyzes them from both economic and environmental points of view in terms of saved money and saved $\mathrm{CO}_{2}$ amount by employing a domestic energy source (i.e. geothermal) rather than an imported one (i.e. natural gas).

In the next section, an overview of Dikili geothermal region is given together with the region's geology, tectonic setting and hydrogeological outlook. Then, the methodology employed for resource assessment using the available data is explained. After that, results obtained and key conclusions drawn from this study are presented.

\section{Study area: Dikili geothermal region}

In this study, an area surrounding Dikili region, which includes Bergama in the south, Dikili and Ayvalık on the west coast, and Madra Mountain in the north is considered (Fig. 1). The area has a semiarid climate with an annual average temperature of $16.5^{\circ} \mathrm{C}$ [13]. In almost half of the year, there is a need for heating considering the months with a temperature below $18{ }^{\circ} \mathrm{C}$ [12]. Hydrothermal systems have been discovered surrounding the Madra Mountain (Fig.1a). NE-SW trending Kozak Pluton, forming mountains of 500-800 m surrounded by Yuntdağ Volcanites, may be a hot dry rock system. This study considers direct or indirect utilization of the hydrothermal resource (considering Yuntdağ volcanites as the reservoir rock) and enhanced geothermal systems (considering Kozak Pluton as the reservoir rock).

The area has been active in terms of development for district heating, greenhouse heating and thermal tourism since early 2000's [18], with geothermal-related exploration activities going back to 1940's [23]. According to recent surveys, 2000 residences ( [28], assuming $100 \mathrm{~m}^{2}$ floor area per residence) and greenhouses of 1,000,000 $\mathrm{m}^{2}$ [27] were being geothermally heated via wells with temperatures ranging from 41.5 to $131.4^{\circ} \mathrm{C}$ [44].

\subsection{Geological outlook}

Figure $1 \mathrm{~b}$ shows the geology map for the region, where Madra Mountain and surroundings can be seen [25]. 


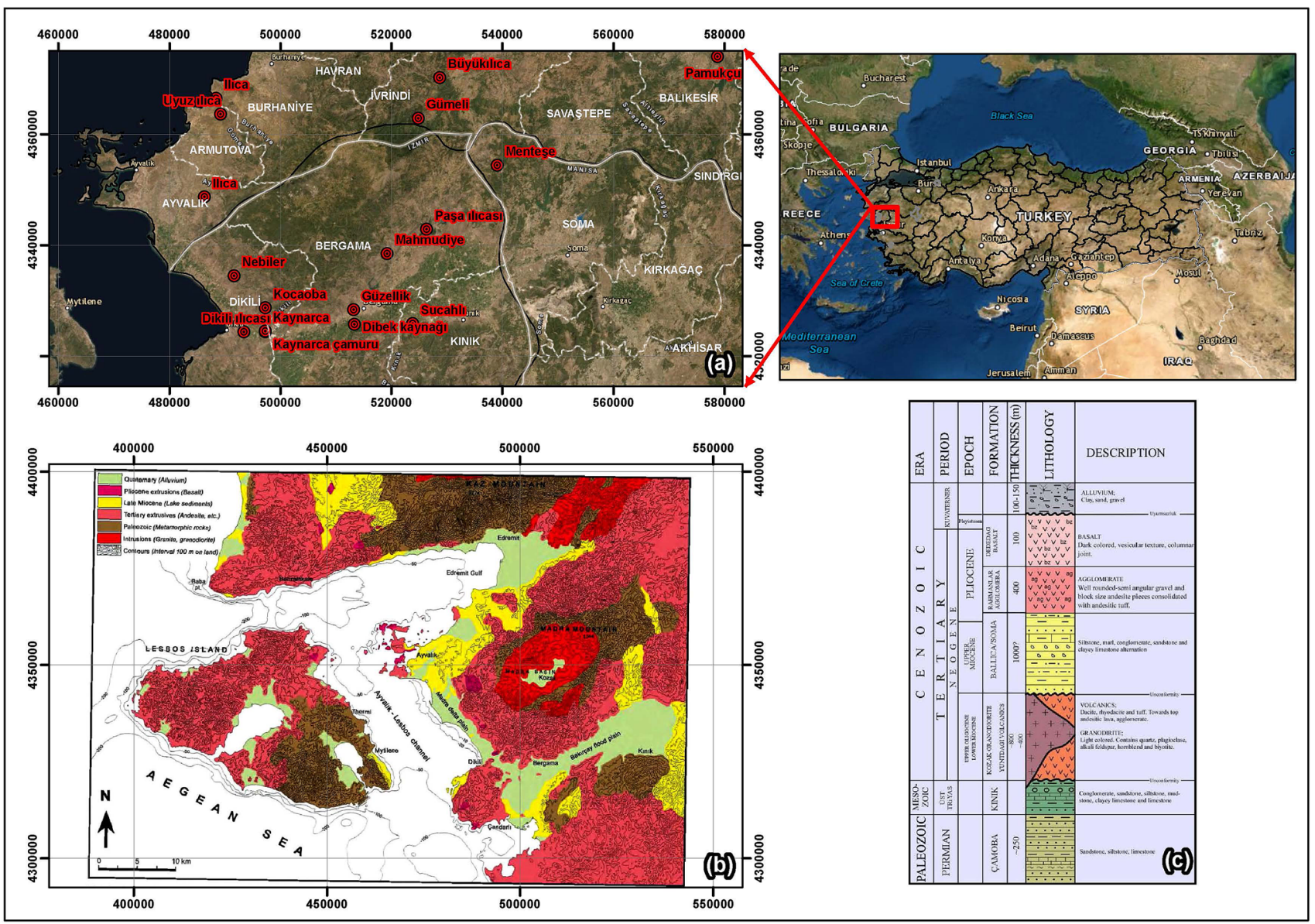

Fig. 1 Dikili geothermal region: a location map [36], b geological map [25], c generalized columnar section [36]

Eight formations are defined in the study area. Figure 1c illustrates subsurface formation characteristics with a generalized stratigraphic columnar succession. At the top, there is the Quaternary alluvium which has a thickness of 100-150 m. From youngest to oldest, the formations below Quaternary alluvium are shown in Table $1[3$, $20,33,36]$. Yuntdağ unit has a fractured structure due to tectonism and hydrothermal alterations. This helps them to behave as a reservoir rock. Soma Formation and the thick tuff/marl layers within Yuntdağ Volcanites occasionally behave like a cap rock. The heat source is stated as being derived from both tectonism and volcanism, [29], radioactive decay in Kozak Pluton [20] or shallow magma [34]. Crustal structure and magmatic intrusions in an extensional tectonic environment are illustrated in Fig. 2a. It is known that thin continental crust and plutonic intrusions jointly are responsible for the high geothermal heat which could also cause the local anomalies in heat-flow maps.
Table 1 Formation characteristics of the columnar stratigraphy in Dikili region $[3,20,33,36]$

\begin{tabular}{|c|c|c|}
\hline Formation & $\begin{array}{l}\text { Average } \\
\text { thickness } \\
\text { (m) }\end{array}$ & Composition \\
\hline Pliocene Dedebağ & 100 & Basalts \\
\hline Pliocene Rahmanlar & 400 & Agglomerate \\
\hline Upper Miocene Soma & 1000 & $\begin{array}{l}\text { Siltstone, marl, conglomerate, } \\
\text { sandstone, clayey limestone }\end{array}$ \\
\hline \multirow[t]{3}{*}{ Yuntdağ volcanites } & \multirow[t]{3}{*}{400} & I: Altered sandstone \\
\hline & & $\begin{array}{l}\text { II: Dark compact basalt, pyrox- } \\
\text { ene andesite, hornblende } \\
\text { andesite }\end{array}$ \\
\hline & & $\begin{array}{l}\text { III: Rhyolite, hornblende, bio- } \\
\text { tite andesite and dacite }\end{array}$ \\
\hline Kozak Pluton & 800 & Granodiorite \\
\hline Mezoic Kınık & 400 & $\begin{array}{l}\text { Conglomerate, sandstone, } \\
\text { siltstone, mudstone, clayey } \\
\text { limestone, limestone }\end{array}$ \\
\hline Permian Çamoba & 250 & Sandstone, siltstone, limestone \\
\hline
\end{tabular}



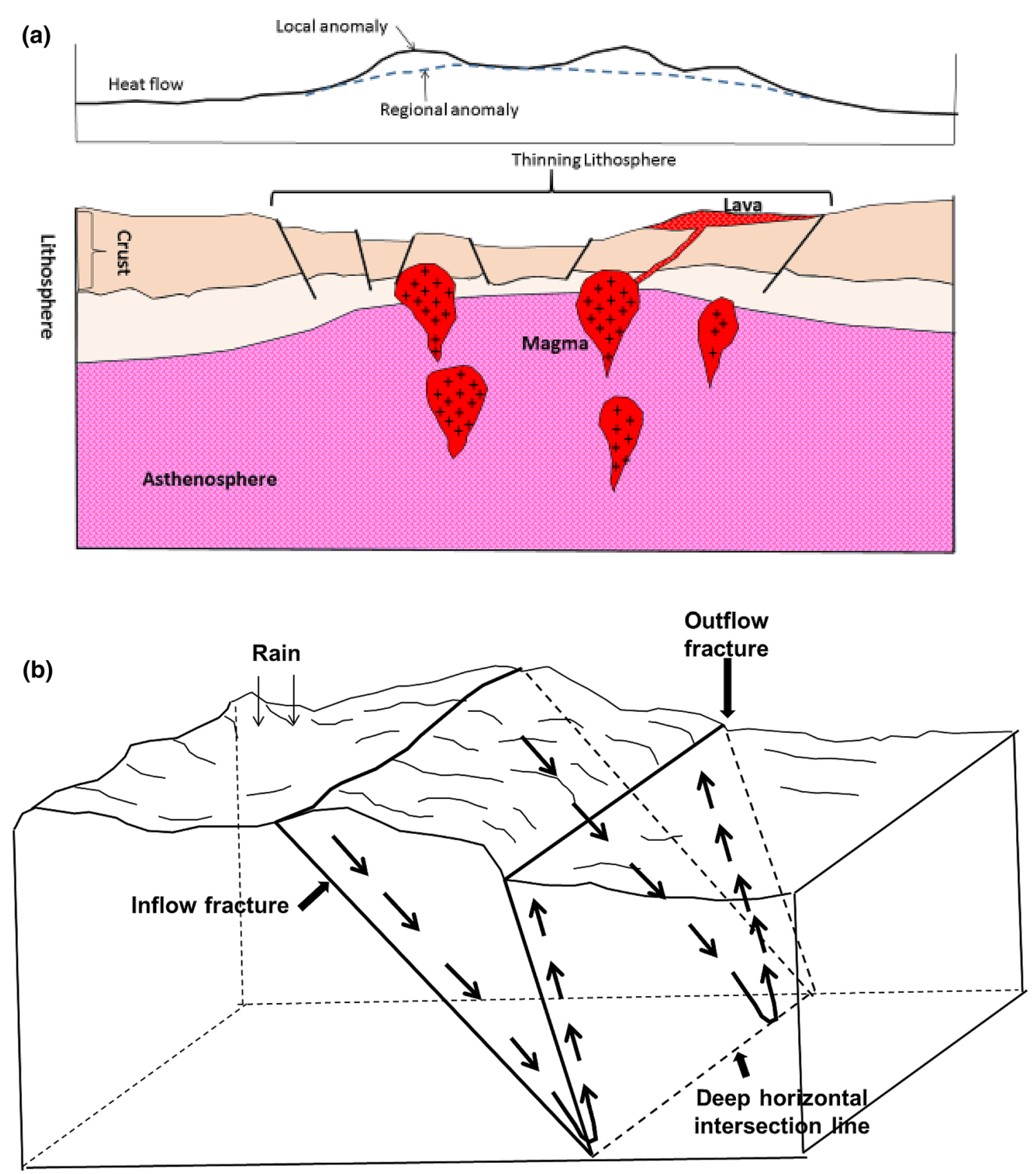

Fig. 2 Schematic models of the study area: a thin earth crust and plutonic intrusions developed to explain high heat flow and associated thermal resources, $\mathbf{b}$ fracture and geomorphological factors in the flow mechanism of hot springs

\subsection{Tectonic setting}

Dikili is located in Western Anatolia, a tectonically active region with rapidly extending, crustal thinning zones. The extension rate is estimated to be around $14 \pm 5 \mathrm{~mm} /$ year [10]. This extensional regime in the $\mathrm{N}-\mathrm{S}$ orientation [47] causes grabens to exist in the $\mathrm{E}-\mathrm{W}$ direction $[2,45]$. The $2 \mathrm{D}$ inversion results of an earlier study investigating the deep resistivity structure of the Dikili-Bergama region with a focus on geothermal potential revealed very low conductivity zones corresponding to the geothermal activity of the hot springs in the region and major fault zones bounding the Dikili depression in NW-SE direction and the Bergama graben in $\mathrm{E}-\mathrm{W}$ direction [47]. All geothermal occurences in the region are linked with Yuntdağ Volcanites around the Madra Mountain. The distribution of these occurences is controlled by fracture patterns [21, 42]. According to our research of existing studies and data, water seeping into deep fractures in Kozak Pluton is heated at depth [33]. These fractures intersect with active graben faults. This creates a path for the 
heated water to reach the surface. Water table elevation in Kozak fractures is higher than the elevations of graben fault traces on the surface. This builds a hydrostatic pressure for water to form hot springs on the surface.

In the region, hot springs and geothermal drilling sites are in normal fault zones which act as discharge pathways for hot water. The origin and geometry of intake and discharge fractures are different. The fluid flow dynamics of a geothermal spring is closely related with the geometry of intersection line between intake and discharge fractures. Figure $2 b$ illustrates these fracture patterns and geomorphological factors in play. Several fracture or fault intersection models and their effects on hot spring occurrences are shown in Fig. 3 [43].

\subsection{Hydrogeological outlook}

Dikili region hosts a number of hot springs with temperatures ranging between 30 and $100{ }^{\circ} \mathrm{C}$ [40]. Radioactive isotope chemistry and stable isotope studies indicate that the thermal waters have existed for more than 50 years [33] and they are of meteoric origin $[9,33,36]$. They get recharged in Kozak, heated at depth and moved up to the surface along the faults $[33,35]$. The types of thermal waters are $\mathrm{Na}-\mathrm{HCO}_{3}^{-}-\mathrm{SO}_{4}^{-}$in Dikili $[9,36], \mathrm{Na}-\mathrm{SO}_{4}^{-}-\mathrm{HCO}_{3}^{-}$in Kaynarca and $\mathrm{NaCa}-\mathrm{SO}_{4}^{-}$in Kocaoba [33, 35]. $\mathrm{SO}_{4}^{-}$is dominant in thermal waters coming from depths of $500-700 \mathrm{~m}$ whereas $\mathrm{HCO}_{3}^{-}$is dominant for thermal waters coming from $700 \mathrm{~m}$. Rather low content of $\mathrm{SO}_{4}^{-}$and $\mathrm{HCO}_{3}^{-}$, high content of $\mathrm{Cl}^{-}$due to mixing with seawater [8] are signs of shallow and not too hot origin of spring waters [40]. Thermal waters in the study area are slightly acidic most probably due to the contact with carbonates [37].

\section{Methodology}

\subsection{Probabilistic resource assessment}

To estimate the resource base, volumetric method is the most commonly used approach in which heat energy stored in the reservoir $\left(Q_{t}, \mathrm{~kJ}\right)$ is taken as equal to the sum of heat stored in certain volume of rock (solid part, $Q_{s}, \mathrm{~kJ}$ ) and water (fluid part, $Q_{w}, \mathrm{~kJ}$ ) for a liquid-dominated reservoir:

$Q_{t}=Q_{s}+Q_{w}$

Extracting the terms for heat content calculations:

$Q_{t}=\underbrace{(1-\phi) c \rho A h \Delta T}_{\text {rock }}\left(Q_{s}\right)+\underbrace{\phi c \rho A h \Delta T}_{\text {water }}\left(Q_{w}\right)$

where $\phi$ is the porosity of the rock (fraction), $c$ is the specific heat capacity $\left(\mathrm{kJ} / \mathrm{kg}^{\circ}{ }^{\circ} \mathrm{C}\right), \rho$ is the density $\left(\mathrm{kg} / \mathrm{m}^{3}\right), A$ is the area of the reservoir $\left(\mathrm{m}^{2}\right), h$ is the thickness of the reservoir $(\mathrm{m})$, and $\Delta T$ is the difference between rock/fluid $\left(T_{r}\right.$, ${ }^{\circ} \mathrm{C}$ ) and utilization temperatures $\left(T_{u},{ }^{\circ} \mathrm{C}\right)$. The recoverable heat energy $(R H E, \mathrm{~kJ})$ can be calculated as:

$R H E=\frac{Q_{t} \times R F}{t \times L F}$

where $R F$ is the recovery factor (fraction), $t$ is the project life (seconds), $L F$ is the load factor (fraction). Load factor is the ratio of total time in which the system is active in a year. Net electrical or thermal power $\left(\mathrm{MW}_{e}\right.$ or $\left.\mathrm{MW}_{t}\right)$ can be calculated as:

$N E P$ or NTP $=C F \times R H E$

where $C F$, the conversion factor (fraction), represents the efficiency of heat exchangers for direct utilization (net thermal power). For indirect utilization (net electrical power), it represents the efficiency of all system components. In the next section, how input parameters of this model were determined is explained.

\subsubsection{Reservoir characteristics}

Reservoir characteristics (porosity, area, thickness, rockfluid temperature, rock density, fluid density, and recovery factor) are considered as uncertain parameters. They are assumed to have triangular distributions, except rock density which has a uniform distribution. They are quantified based on the data from the literature as explained below:

- Porosity: Porosity is assumed to follow a triangular distribution as also presented in similar studies $[6,7$, 38]. Considering the range of porosity for granodiorite and andesites [39], 0.01 and 0.03 were chosen as the minimum and maximum values respectively. The mostlikely value for porosity is taken as 0.0129 for Yuntdağ Volcanites, and 0.02 for Kozak Pluton [20].

- Area: Because of not having access to an accurate estimation of the areal extent of Yuntdağ Volcanites, a visual interpretation resulted in the following triangular distribution: $1.5 \times 10^{7} \mathrm{~m}^{2}, 3.0 \times 10^{7} \mathrm{~m}^{2}$, and $4.5 \times 10^{7} \mathrm{~m}^{2}$ as minimum, most likely and maximum values, respectively. The area of the artificial EGS reservoir is taken as $3.3 \times 10^{5} \mathrm{~m}^{2}$ (min.), $8.8 \times 10^{5} \mathrm{~m}^{2}$ (most likely), $2.21 \times 10^{6}$ $\mathrm{m}^{2}$ (max.) for Kozak Pluton considering two horizontal wells for injection and production (Fig. 4). The area is calculated based on the horizontal well length and distance between wells which determines the reservoir area utilized.

- Thickness: The range of the triangular distribution was found by considering the formations in the region's subsurface stratigraphy. Minimum thickness includes 

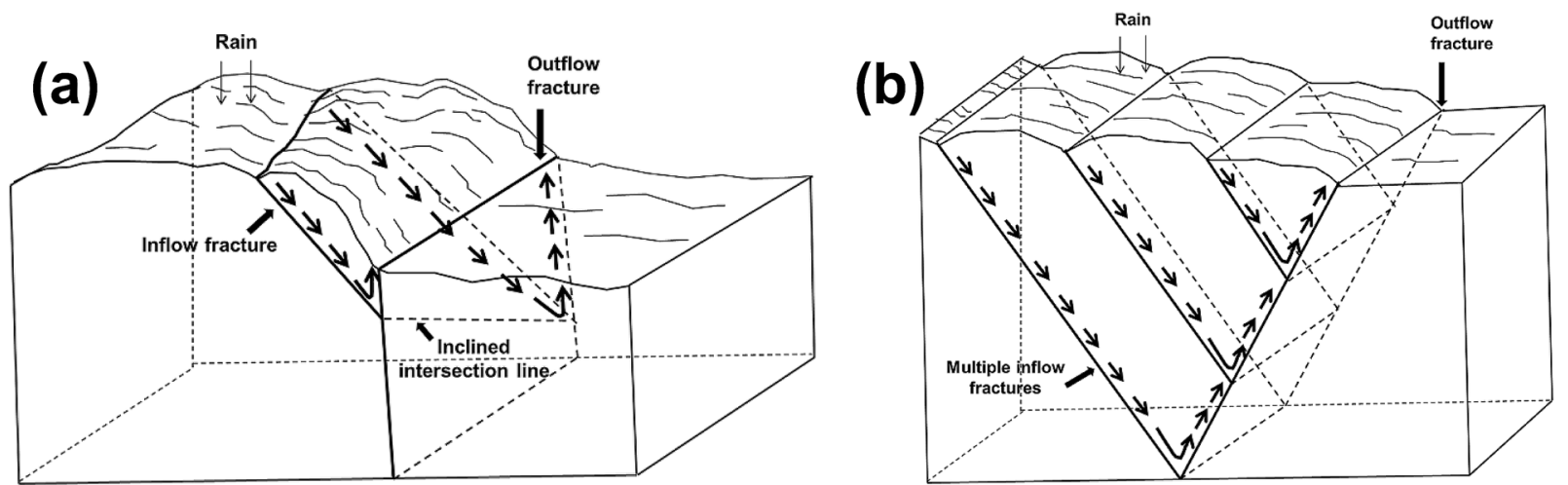

(c)

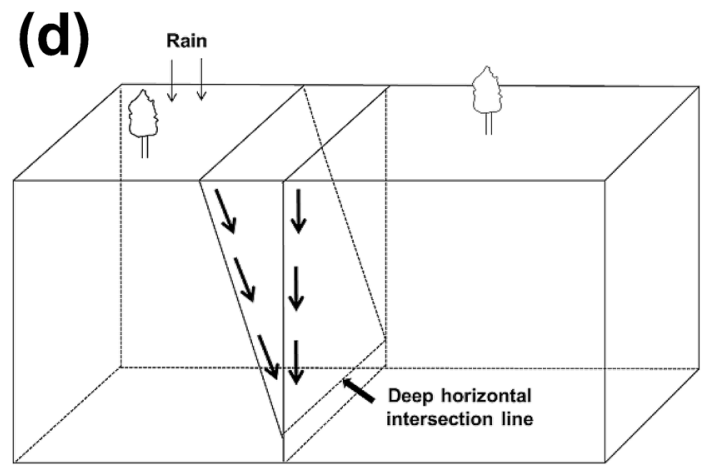

(e)
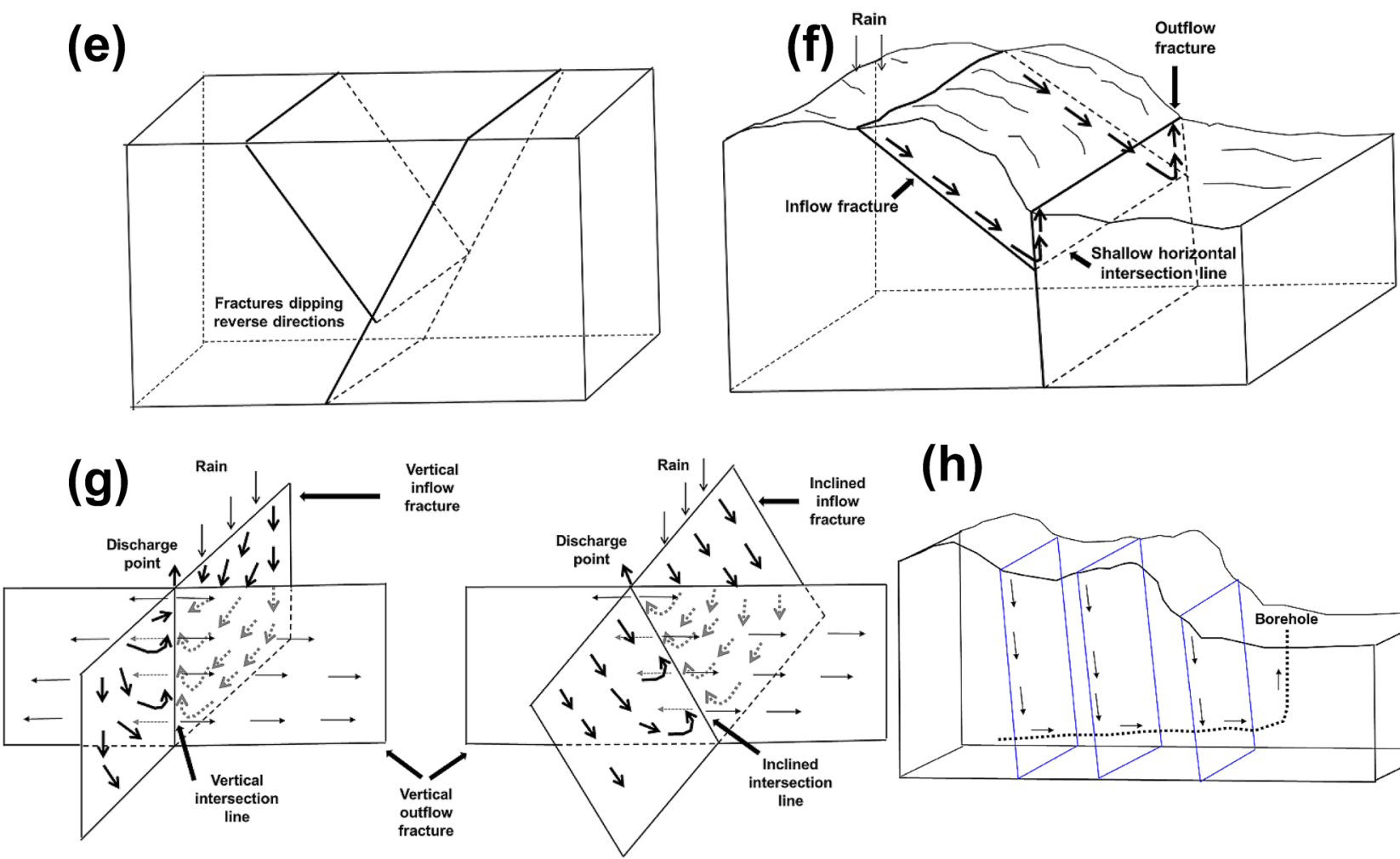

(h)

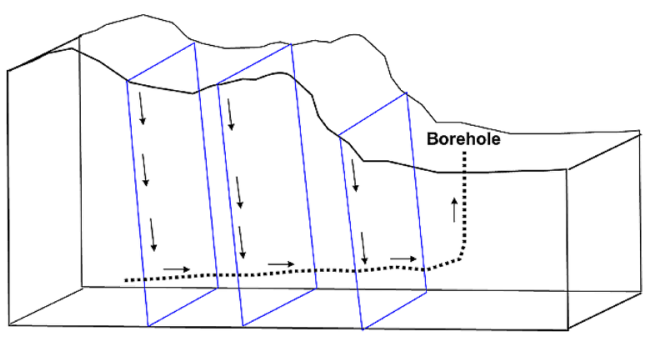

Fig. 3 Schematic illustration of fracture or fault intersection models [43]: a Oblique strikes of outflow and inflow fractures, $\mathbf{b}$ outflow fracture intersecting multiple inflow fractures, c multidirectional fractured rocks, $\mathbf{d}$ intersecting fractures in a flat terrain, e fractures of parallel strikes, $\mathbf{f}$ Shallow intersecting parallel strike fractures, $\mathbf{g}$ intersection of unparalleled fracture planes, $\mathbf{h}$ non-intersecting parallel fracture planes 


\section{Minimum}
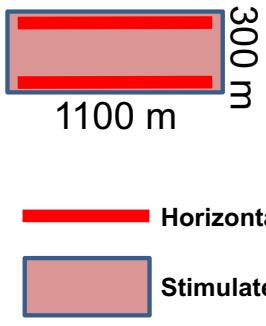

Horizontal well

Stimulated reservoir
Most likely

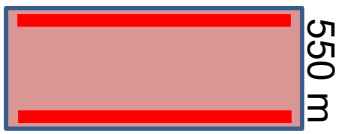

$1600 \mathrm{~m}$

\section{Maximum}

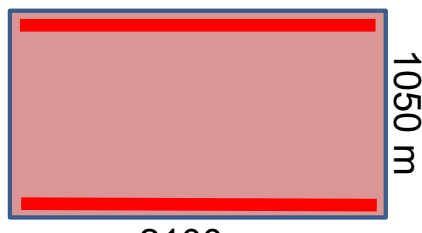

$2100 \mathrm{~m}$

Top view

Fig. 4 Sample configuration of well layout and stimulated reservoir area from the top view (not to scale)

the cap rock and the reservoir rock. Most likely includes one additional formation below the reservoir rock. Maximum includes all formations. This definition is shown in Fig. 5. During borehole drilling, thickness of Yuntdağ Volcanites-1 and Soma Formation were found as 300 and 200 m., respectively. The thickness of Kozak Pluton and Kınık Formation were uncertain. Therefore, by considering other published studies [36], 2150, 2400 and $2800 \mathrm{~m}$. were used for minimum, most likely and maximum for Kozak-EGS application. For Yuntdağ Volcanites, 500, 1300, and $1950 \mathrm{~m}$ were used [20].

- Recovery factor: Recovery factor in geothermal resources represents the fraction of the total heat that is convected by fluid from the rock to the surface. 0.07 , 0.18 and 0.24 were chosen as the minimum, most likely, and maximum values, respectively, as also used in [31].

- Rock and fluid temperature: $96^{\circ} \mathrm{C}, 165^{\circ} \mathrm{C}, 237^{\circ} \mathrm{C}$ were used as the minimum, most likely, and maximum values, respectively, for Kozak Pluton based on existing geothermometry studies [20]. $64.2^{\circ} \mathrm{C}, 93^{\circ} \mathrm{C}, 145^{\circ} \mathrm{C}$ were used for Yuntdağ Volcanites by analyzing the cumulative distribution function of measured wellbottom temperatures in the region [44].
- Rock density: Because of its nature, a uniform distribution was defined for rock density by assuming a range between 2500 and $2800 \mathrm{~kg} / \mathrm{m}^{3}$ for igneous rocks [39].

- Fluid density: The salinity was measured as 3000 ppm for Dikili hydrothermal system [46]. Considering a depth of $1420 \mathrm{~m}$. and a pressure gradient of $0.433 \mathrm{psi} /$ $\mathrm{ft}$, an average reservoir pressure was found as $2017 \mathrm{psi}$. Using salinity-temperature-pressure-density relationship, a triangular distribution was defined with values of $945 \mathrm{~kg} / \mathrm{m}^{3}, 980 \mathrm{~kg} / \mathrm{m}^{3}$ and $995 \mathrm{~kg} / \mathrm{m}^{3}$.

Specific heat capacities for rock and water were taken as constants:

- For andesite (Yuntdağ): $0.965 \mathrm{~kJ} / \mathrm{kg}-{ }^{\circ} \mathrm{C}$ [39]

- For granodiorite (Kozak): $1090 \mathrm{~kJ} / \mathrm{kg}^{\circ}{ }^{\circ} \mathrm{C}$ [39]

- For water in Yuntdağ, $4.14 \mathrm{~kJ} / \mathrm{kg}^{\circ}{ }^{\circ} \mathrm{C}$ is used, which corresponds to the most-likely temperature of the reservoir $\left(93^{\circ} \mathrm{C}\right)$

- For water in Kozak, $4.26 \mathrm{~kJ} / \mathrm{kg}-{ }^{\circ} \mathrm{C}$ is used, which corresponds to the most-likely temperature of the reservoir $\left(163^{\circ} \mathrm{C}\right)$
Fig. 5 Illustration of formation sequences of Kozak-EGS and Yuntdag hydrothermal system, and thickness definitions for the minimum, most likely and maximum estimates (not to scale)

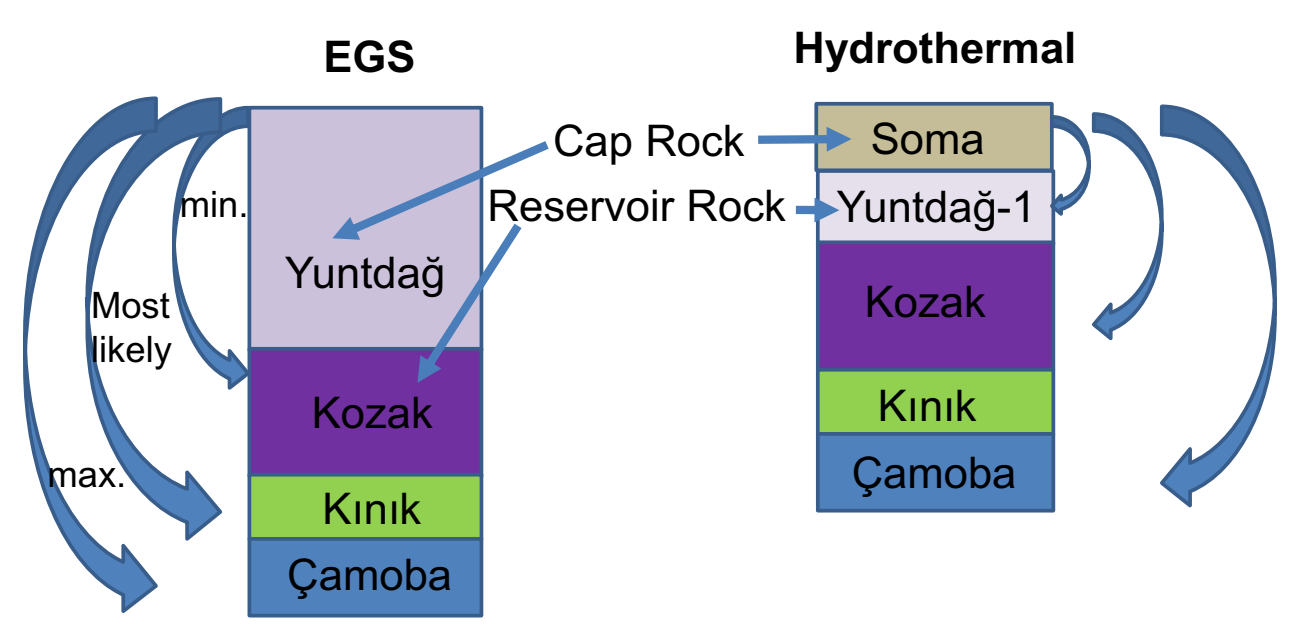




\subsubsection{Operational parameters and development scenarios}

Operational parameters are taken as constants since the main objective of this study is to analyze the impact of uncertain reservoir characteristics. Project life was assumed to be 30 years as a typical project development and utilization cycle for geothermal resources [17]. For direct utilization (heating), load factor was taken as 0.50 considering the climate data of Dikili region [13]. For indirect utilization (electricity), the load factor was taken as 0.95 considering the maintenance time for power plants. The conversion factor was taken as 0.12 for indirect utilization and as 0.95 for direct utilization as also used in [17]. The minimum measured well temperature in the region is $41.5^{\circ} \mathrm{C}$. This temperature was defined as the utilization temperature for direct utilization (heating). For indirect utilization, a rejection temperature of $60{ }^{\circ} \mathrm{C}$ was used considering the possibility of scaling under this temperature.

Figure 6 shows a summary structure of the probabilistic assessment carried out for the geothermal resources of Dikili. Both real and unit volumes are considered to understand the potential in both terms. Kozak and Yuntdağ reservoirs are considered for both direct and and indirect utilization. This helped us to analyze a wide array of possibilities regarding the development of these resources.

\subsection{Critical analysis}

The sustainability attributes of the presented scenarios were evaluated by both from environmental and economic perspectives. The potential reduction in the $\mathrm{CO}_{2}$ emission amount by utilizing these resources instead of natural gas was estimated. It is estimated that typical geothermal power plants emit around $15 \%$ of what a natural gas plant would emit to generate the same amount of power [11]. To estimate the amount of $\mathrm{CO}_{2}$ emitted during the natural gas combustion process, the following assumptions are considered:

- Pure methane $\left(\mathrm{CH}_{4}\right)$ is considered as natural gas with a density of $0.7 \mathrm{~kg} / \mathrm{m}^{3}$, which yields $8250 \mathrm{kcal}$ of energy when combusted. Combustion reaction of methane and oxygen is:

$$
\mathrm{CH}_{4}+2 \mathrm{O}_{2} \longrightarrow \mathrm{CO}_{2}+2 \mathrm{H}_{2} \mathrm{O}
$$

According to this reaction, when 1 mole $(16 \mathrm{~g})$ of $\mathrm{CH}_{4}$ gets into the combustion reaction, 1 mole $(44 \mathrm{~g})$ of $\mathrm{CO}_{2}$ gets released to the atmosphere. It is assumed that there is not any $\mathrm{CO}_{2}$ capture mechanism in the power plant and it is fully released to the atmosphere.

With these assumptions, $\mathrm{CO}_{2}$ generated $(\mathrm{kg})$ per year by utilizing a natural gas $\left(\mathrm{CH}_{4}\right)$ power plant can be estimated from the following equation:

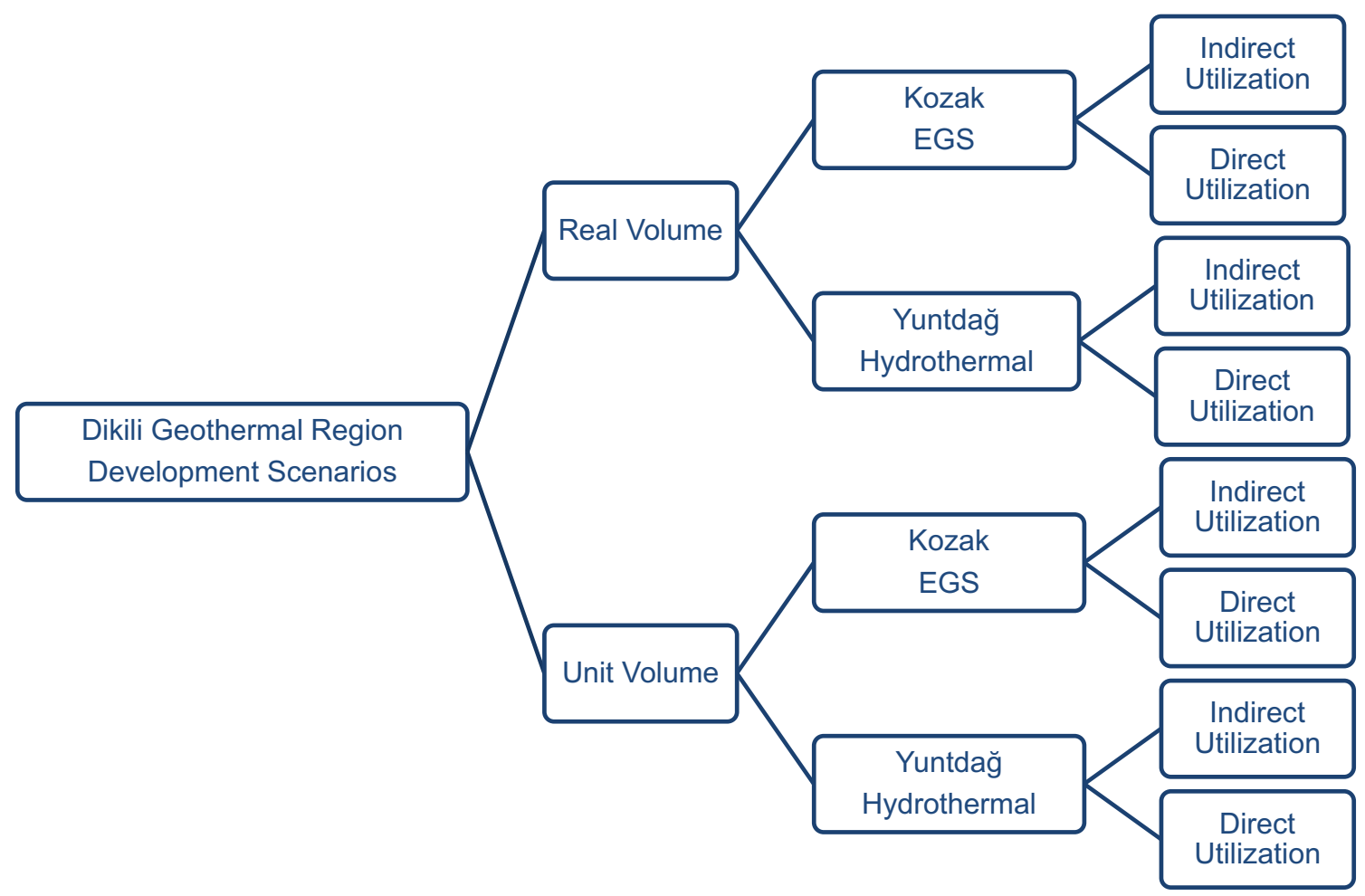

Fig. 6 Development scenarios with different utilization ways of Yuntdağ and Kozak reservoirs. Both real and unit volumes are considered 
Annual kg of $\mathrm{CO}_{2}=(N E P)\left(\frac{7.54 \times 10^{6} \mathrm{kcal}}{1 \text { year }}\right)\left(\frac{1 \mathrm{~m}^{3}}{8,250 \mathrm{kcal}}\right)\left(\frac{0.7 \mathrm{~kg}}{1 \mathrm{~m}^{3}}\right)\left(\frac{44 \mathrm{~g}}{16 \mathrm{~g}}\right)$

where NEP is the net electrical power in MW. To estimate the economic benefits of utilizing the geothermal resources, the following assumptions are considered:

- Based on average European Union natural gas import prices in 2019, natural gas costs $\$ 170$ per $1000 \mathrm{~m}^{3}$ [16].

- There is no $\mathrm{CO}_{2}$ incentive or tax regulation taken into account as it is now in Turkey [32]. However, $\mathrm{CO}_{2}$ tax regulation such as 13.6 euro per ton of $\mathrm{CO}_{2}[19]$ is also considered as a future possibility. Therefore, this regulation is also included to see the potential benefit from the operating company's perspective.

- The efficiency of the natural gas cycle power plant is $50 \%$.

Therefore, the economic burden of imported natural gas on Turkish economy can be calculated from:

\section{Results and discussion}

Monte Carlo simulations were carried out with 10,000 simulations by generating scenarios considering the statistical distribution of each input parameter. For each scenario, net thermal power and net electrical power were computed and their cumulative probability distributions (expectation curves) were obtained. Figures 7 and 8 show these curves for Yuntdağ and Kozak, respectively, for real volume calculations that consider the estimated extent of the reservoir areally and vertically. Table 2 shows the values that correspond to the cumulative probabilities of $10 \%, 50 \%$ and $90 \%$. These values represent the probabilities to have the resource base at a given level. Therefore, $90 \%$ can be considered as the high-confidence case, $50 \%$ can be considered as

Annual cost of natural gas per year $=\frac{\text { Vol. purchased }\left(\mathrm{m}^{3}\right)}{1 \text { year }} \frac{\$ 170}{1000 \mathrm{~m}^{3}} \frac{1}{0.5}$

Table 2 Power output of each case in with 10\%, 50\% and $90 \%$ probability, respectively (for real volume of reservoirs)

\begin{tabular}{lllll}
\hline & \multicolumn{3}{l}{ Cumulative probability (\%) } \\
\cline { 3 - 5 } & 10 & 50 & 90 \\
\hline Kozak-EGS & Indirect $\left(\mathrm{MW}_{e}\right)$ & 32 & 17 & 8 \\
& Direct $\left(\mathrm{MW}_{t}\right)$ & 560 & 300 & 150 \\
\multirow{3}{*}{$\begin{array}{l}\text { Yuntdag-hydro- } \\
\text { thermal }\end{array}$} & Indirect $\left(\mathrm{MW}_{e}\right)$ & 150 & 75 & 30 \\
& Direct $\left(\mathrm{MW}_{t}\right)$ & 3148 & 1700 & 850 \\
\hline
\end{tabular}

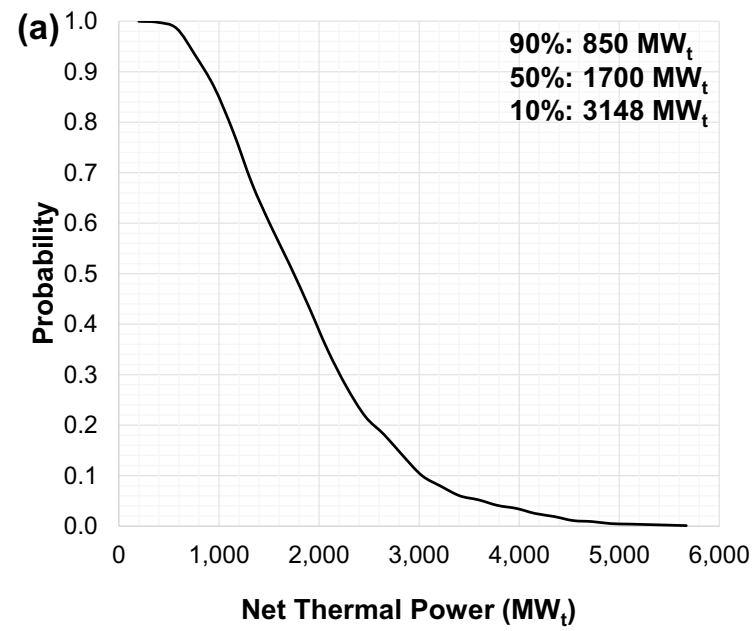

the mid-confidence (or most-likely) case, and $10 \%$ can be considered as the low-confidence case. These results show that Yuntdağ hydrothermal reservoir can produce 4.4 times more electrical power than Kozak, with 50\% probability. Similarly, Yuntdağ has the potential to produce 5.7 times more thermal power than Kozak. Therefore, when the full areal and vertical extent of these resources are considered, Yuntdağ has a more prolific potential than Kozak. Based on $90 \%$ probability estimates, Yuntdağ has the potential of providing 4.2 times

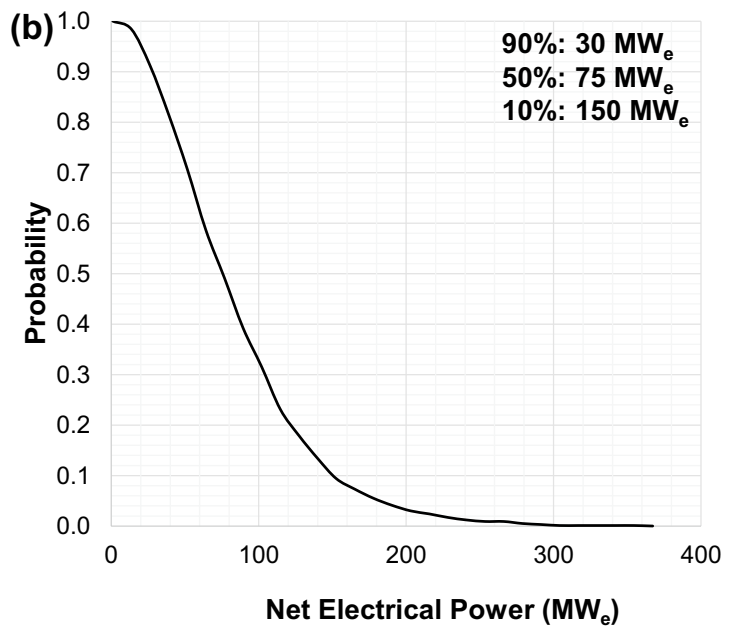

Fig. 7 Cumulative expectation curve for Yuntdağ hydrothermal reservoir for real-volume case a direct utilization, b indirect utilization 

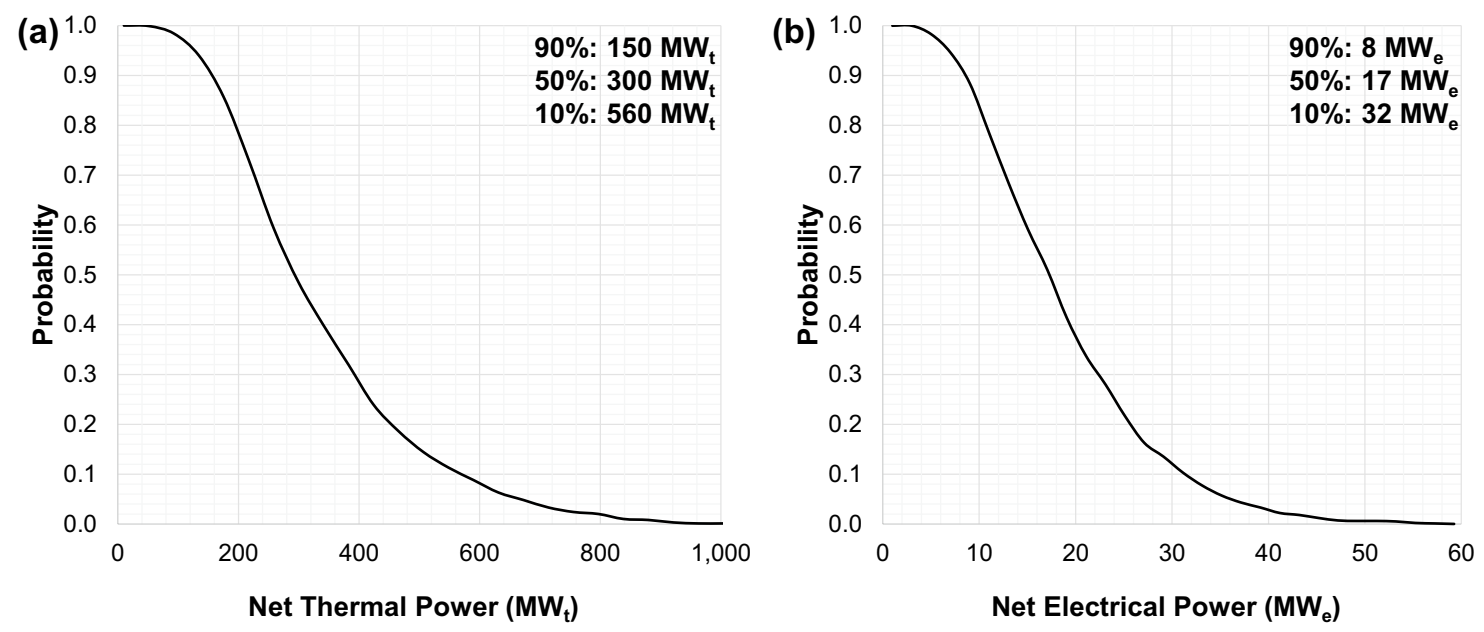

Fig. 8 Cumulative expectation curve for Kozak-EGS reservoir for real-volume case a direct utilization, $\mathbf{b}$ indirect utilization

Table 3 Power output of each case in with 10\%, 50\% and $90 \%$ probability, respectively (for unit volume of reservoirs)

\begin{tabular}{lllll}
\hline & & \multicolumn{3}{c}{ Cumulative probability (\%) } \\
\cline { 3 - 5 } & 10 & 50 & 90 \\
\hline Kozak-EGS & ${\text { Indirect }\left(\mathrm{MW}_{e}\right)}$ & $1.01 \mathrm{E}-08$ & $6.70 \mathrm{E}-09$ & $3.80 \mathrm{E}-09$ \\
& Direct $\left(\mathrm{MW}_{t}\right)$ & $1.72 \mathrm{E}-07$ & $1.18 \mathrm{E}-07$ & $7.20 \mathrm{E}-08$ \\
$\begin{array}{l}\text { Yuntdag- } \\
\begin{array}{c}\text { hydrother- } \\
\text { mal }\end{array}\end{array}$ & Dindirect $\left(\mathrm{MW}_{e}\right)$ & $3.74 \mathrm{E}-09$ & $2.10 \mathrm{E}-09$ & $1.00 \mathrm{E}-09$ \\
& Direct $\left(\mathrm{MW}_{e}\right)$ & $7.50 \mathrm{E}-08$ & $4.80 \mathrm{E}-08$ & $2.80 \mathrm{E}-08$ \\
\hline
\end{tabular}

more thermal production in the region. This corresponds to 4.17 million $\mathrm{m}^{2}$ greenhouse heating or heating of 95,031 residences, assuming $100 \mathrm{~m}^{2}$ of floor area per residence.

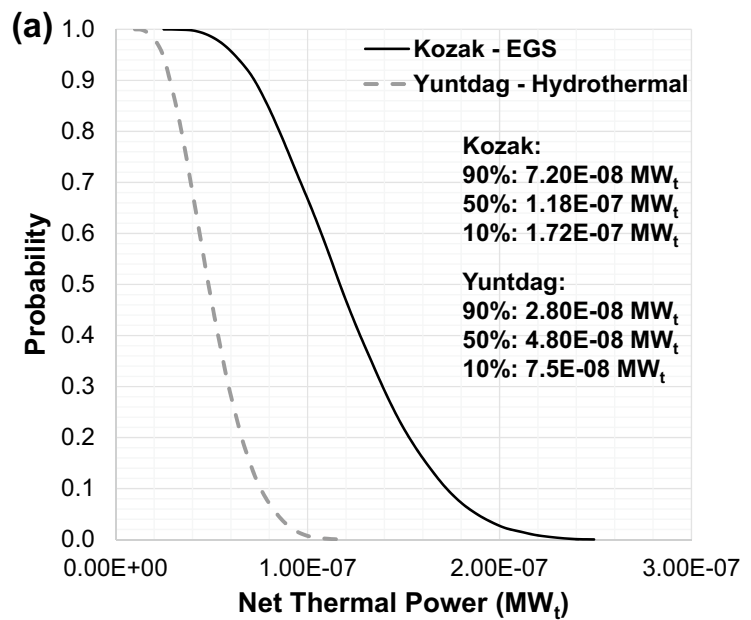

Unit volume based assessment is also important to have a comparison regarding the efficient extraction of the resource base. Probabilistic assessment was performed for $1 \mathrm{~m}^{3}$ of reservoir volume for both reservoirs. Figure 9 shows the expectation curves for both direct and indirect utilization options. Table 3 shows the values that correspond to the cumulative probabilities of $10 \%$, $50 \%$ and $90 \%$. In this case, Kozak has the potential of producing 3.2 and 2.5 times more power than Yuntdağ, considering indirect and direct utilization, respectively.

A sensitivity analysis was completed to understand the importance of input variables regarding the resource assessment calculations. This was performed using onevariable-at-a-time approach (OVAT), in which, only one variable is varied within its own range, while keeping the other variables at their most-likely values. By computing the resource base in each step, a tornado chart can

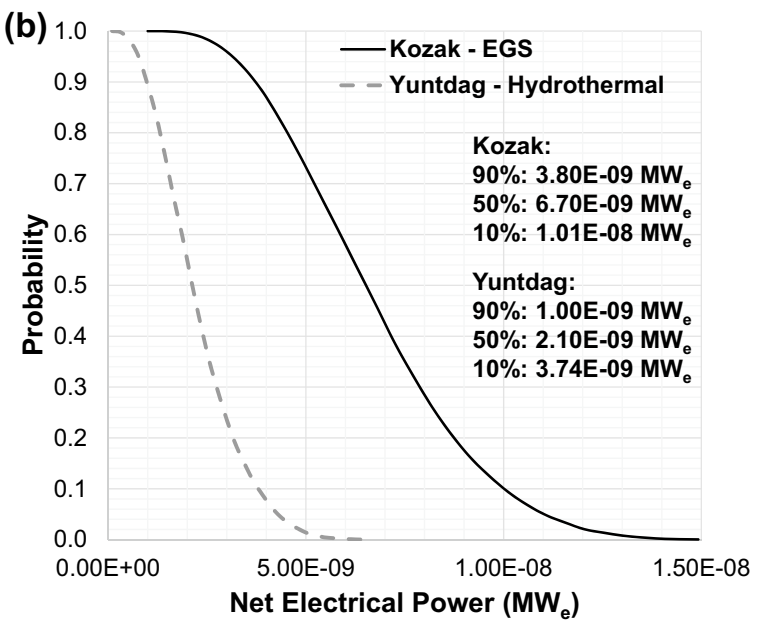

Fig. 9 Cumulative expectation curve for unit-volume case $\mathbf{a}$ direct utilization, $\mathbf{b}$ indirect utilization 
(a)

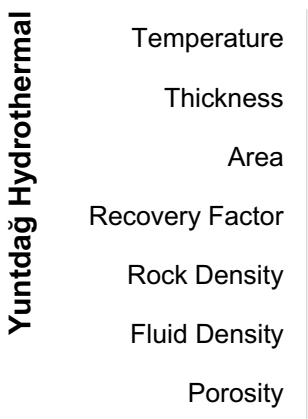

Net Thermal Power $\left(\mathrm{MW}_{\mathrm{t}}\right)$

$0 \quad 1000 \quad 2000 \quad 3000 \quad 4000 \quad 5000$

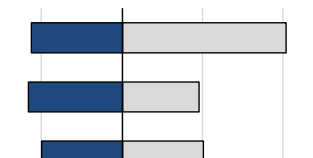

(b)

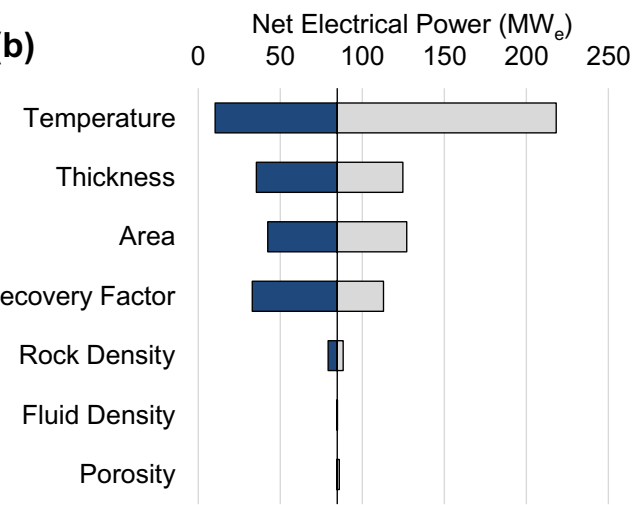

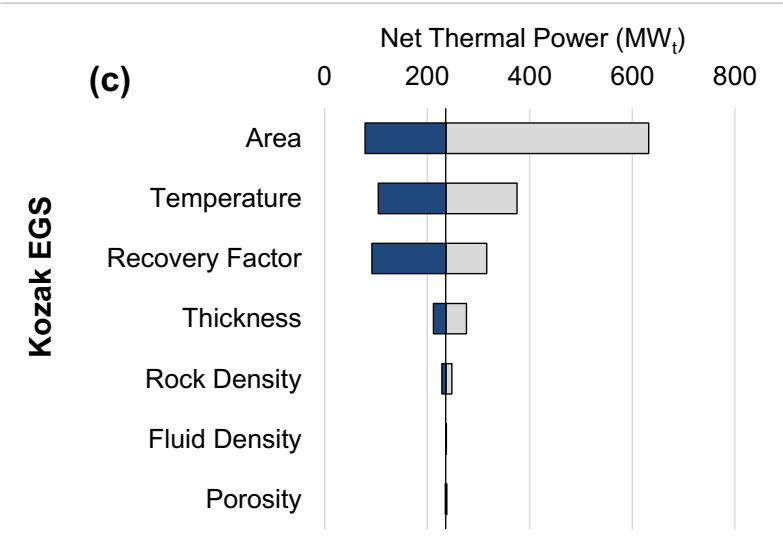

(d)

Net Electrical Power $\left(\mathrm{MW}_{\mathrm{e}}\right)$

d)

Area

Temperature

Recovery Factor

Thickness

Rock Density

Fluid Density

Porosity $\begin{array}{llll}10 & 20 & 30 & 40\end{array}$

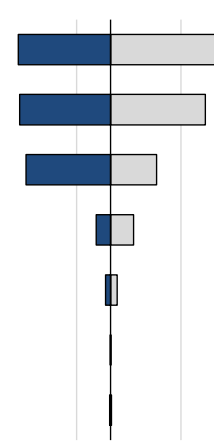

Fig. 10 Tornado charts that show the sensitivity to input parameters: a Yuntdağ hydrothermal direct utilization, b Yuntdağ hydrothermal indirect utilization, c Kozak EGS direct utilization, d Kozak EGS indirect utilization

be constructed to analyze the impact of each input variable. Figure 10 shows the tornado charts for both reservoirs and for both utilization options. In these charts, the size of the bars indicate the swing value, which represents the degree of impact. In all cases, reservoir temperature, thickness, area, and recovery factor have a considerable impact on the resource base. For Yuntdağ, temperature is the most important variable. For Kozak, areal extent is the most important variable. Rock density, fluid density and porosity do not have a considerable significance. These results essentially have two meanings for the former four variables that are important: 1) The exact value of these variables affects the resource assessment significantly. Therefore, an increase or decrease in their actual quantities could result in a dramatic change in the assessment. 2) An effort should be made to reduce the uncertainty range for these variables to also reduce the uncertainty in the resource assessment.

To analyze the sustainability attributes of the development of the geothermal resources in Dikili Region, amount of $\mathrm{CO}_{2}$ that would be saved from emission can be estimated. By substituting the most-likely (50\% probability) net electrical power potentials of Kozak and Yuntdağ, 17 and $75 \mathrm{MW}_{e}$, into Eq. 5, it is found out that $30 \mathrm{MM} \mathrm{kg}$ and
$132 \mathrm{MM} \mathrm{kg}$ of $\mathrm{CO}_{2}$, respectively, would be generated by a natural gas power plant in a given year of operation. Since a geothermal power plant would emit approximately $15 \%$ of this amount [11], 85\% would be saved from being emitted into the atmosphere ( 25 and $112 \mathrm{MM} \mathrm{kg}$ ). Even though this is a rough estimate, it demonstrates the potential benefit from an environmental point of view.

The economic benefits can be quantified by considering the economic burden on Turkish economy due to natural gas import. Using Eq. 6, the cost of natural gas to generate Kozak and Yuntdağ's most-likely power potential can be estimated. 17 and $75 \mathrm{MW}_{e}$ correspond to $15.5 \mathrm{MM}$ $\mathrm{m}^{3}$ and $68.6 \mathrm{MM} \mathrm{m}^{3}$ of natural gas per year, respectively. At $\$ 170 / 1000 \mathrm{~m}^{3}$, the costs per year is $\$ 5.3$ million for Kozak, and $\$ 23.5$ million for Yuntdağ. If a tax regulation is in place that allows operating companies to be compensated for the reduction in $\mathrm{CO}_{2}$ emissions (e.g. 13.9 euros per ton of $\mathrm{CO}_{2}$ ), this could be another benefit from the operating companies' perspectives. When the aforementioned reductions of $\mathrm{CO}_{2}$ emission is considered, an operating company could save approximately $\$ 0.35$ million and $\$ 1.6$ million in a given year, for Kozak and Yuntdağ, respectively. These sample high-level calculations altogether highlight some of the sustainability attributes of the potential 
development plans in these reservoirs. More detailed economic and environmental assessments would be necessary to demonstrate the actual feasibility and benefits.

\section{Conclusions}

The following key conclusions are drawn from this study:

1. Based on available data, both Yuntdağ hydrothermal and Kozak EGS can be promising candidates for development for both direct and indirect utilization, in terms of the available resource base. While Yuntdağ has a better potential in terms of real volume, Kozak has a better profile on the unit-volume basis.

2. Sustainability related benefits of these geothermal resources were demonstrated by sample calculations. There could be a reduction of 25 and $112 \mathrm{MM} \mathrm{kg}$ of $\mathrm{CO}_{2}$ emitted per year when Kozak or Yuntdağ is utilized instead of a natural gas power plant.

3. Sensitivity analysis showed that the reservoir size, temperature and recovery factor are the most critical parameters that affect the resource assessment. It was also shown that calculations are not sensitive to rock/ fluid density and porosity, within the specified ranges.

\section{Declarations}

Conflict of interest The authors declare that they have no conflict of interest.

Open Access This article is licensed under a Creative Commons Attribution 4.0 International License, which permits use, sharing, adaptation, distribution and reproduction in any medium or format, as long as you give appropriate credit to the original author(s) and the source, provide a link to the Creative Commons licence, and indicate if changes were made. The images or other third party material in this article are included in the article's Creative Commons licence, unless indicated otherwise in a credit line to the material. If material is not included in the article's Creative Commons licence and your intended use is not permitted by statutory regulation or exceeds the permitted use, you will need to obtain permission directly from the copyright holder. To view a copy of this licence, visit http://creativecommons. org/licenses/by/4.0/.

\section{References}

1. Akın S (2017) Geothermal resource assessment of Alaşehir geothermal field. In: 45th workshop on geothermal reservoir engineering, SGP-TR 212. Stanford, California, pp 13-15

2. Akyürek A, Soysal Y (1983) Biga Yarımadası güneyinin (Savaştepe-Kırkaağac-Bergama-Ayvalık) temel jeoloji özellikleri.
Mineral Research and Exploration Institute of Turkey (MTA) Bulletin 95/96

3. Altunkaynak Ş, Yılmaz Y (1999) The Kozak Pluton and its emplacement. Geol J 34(3):257-274.

4. ARI-ES (2019) İzmir ili Seferihisar ilçesi RSC-1 seferihisar jeotermal enerji santrali 1/1000 ölçekli uygulama imar planı plan açıklama raporu. Retrieved April 2021. https://webdosya.csb. gov.tr/db/izmir/icerikler/1000_aciklama-raporu-2019082713 0103.PDF

5. Arkan S, Parlaktuna M (2005) Resource assessment of Balçova geothermal field. In: World geothermal congress proceedings. Antalya, Turkey, pp 24-29

6. Atmaca I (2010) Resource assessment in Aydın-Pamukören Geothermal Field. M.S. Thesis, Middle East Technical University, Ankara, Turkey

7. Avşar Ö (2011) Geochemical evaluation and conceptual modeling of Edremit Geothermal Field. Ph.D. dissertation, Middle East Technical University, Ankara, Turkey

8. Baba A (2015) Application of geothermal energy and its environmental problems in Turkey. Int J Glob Environ Issues 14(3/4):321-331

9. Baba A, Sözbilir H (2012) Source of arsenic based on geological and hydrogeochemical properties of geothermal systems in Western Turkey. Chem Geol 334:364-377. https://doi.org/10. 1016/j.chemgeo.2012.06.006

10. Bilim F, Akay T, Aydemir A, Koşaroğlu S (2016) Curie point depth, heat-flow and radiogenic heat production deduced from the spectral analysis of the aeromagnetic data for geothermal investigation on the Menderes Massif and the Aegean Region, Western Turkey. Geothermics 60:44-57. https://doi.org/10.1016/j. geothermics.2015.12.002

11. Bloomfield K, Moore J, Neilson R Jr (2003) Geothermal energy reduces greenhouse gases: $\mathrm{CO}_{2}$ emissions from geothermal energy facilities are insignificant compared to power plants burning fossil fuels. Geotherm Resour Council Bull 32(2):77-79

12. Büyükalaca O, Bulut $H$, Yılmaz T (2001) Analysis of variablebase heating and cooling degree-days for Turkey. Appl Energy 69(4):269-283

13. Climate-Data (2016) Climate: Dikili. https://en.climate-data.org/ location/25663/. Retrieved August 30, 2016

14. DPT (2009) Elektrik Enerjisi Piyasası ve Arz Güvenliği Strateji Belgesi, Türkiye Cumhuriyeti, Başbakanlık Devlet Planlama Teşkilatı. Yüksek Planlama Kurulu. Tech. rep, Türkiye Cumhuriyeti, Başbakanlık Devlet Planlama Teşkilatı, Yüksek Planlama Kurulu

15. Enerji Atlası (2021) İzmir elektrik santralleri. Retrieved April 2021. https://www.enerjiatlasi.com/sehir/izmir/

16. EU (2019) European Union natural gas import price-commodity markets review, World Bank. https://ycharts.com/indicators/ europe_natural_gas_price

17. Garg S, Combs J (2015) A reformulation of USGS volumetric'heat in place' resource estimation method. Geothermics 55:150-158. https://doi.org/10.1016/j.geothermics.2015.02.004

18. Güldar S (2014) İzmir İli Enerji Görünümü (2003-2014). Tech. rep, TMMOB Elektrik Mühendisleri Odası İzmir Şubesi, Enerji Komisyonu

19. Hotunluoğlu H, Tekeli R (2007) Analysis and effects of carbon tax: Does carbon tax reduce emission? Sosyo-Ekonomi 3(6):107-126

20. Hou Z, Şen O, Gou Y, Eker AM, Li M, Yal GP, Cambazoğlu S, Were P (2015) Preliminary geological, geochemical and numerical study on the first EGS project in Turkey. Environ Earth Sci 73(11):67476767. https://doi.org/10.1007/s12665-015-4407-6

21. Jeckelmann C (1996) Genese lokaler thermalwasservorkommen in der region Bergama/W-Türkei. Ph.d. Dissertation, Dissertation ETH no. 11990, Zürich, Switzerland

22. JESDER (2021) Kurulu Güç: 1.576 MWe. Retrieved April 2021. https://jesder.org/kurulu-guc-1-576-mwe/ 
23. Kalıncı Y, Hepbaşlı A, Tavman I, (2008) Determination of optimum pipe diameter along with energetic and exergetic evaluation of geothermal district heating systems: modeling and application. Energy Buildings 40(5):455-742. https://doi.org/ 10.1016/j.enbuild.2007.05.009

24. Kaplanoğlu M, Baba A, Akkurt G (2020) Use of abandoned oil wells in geothermal systems in Turkey. Geomech Geophys Geoenergy Georesour 6:2. https://doi.org/10.1007/ s40948-019-00125-0

25. Kayan I, Vardar S (2007) The physical geography of the Madra River Delta, British Institute of Archaeology at Ankara. pp 9-22

26. Korkmaz E, Serpen U, Satman A (2020) Geothermal boom in Turkey: growth in identied capacities and potentials. Renew Energy 68:314-325. https://doi.org/10.1007/s40948-019-00125-0

27. Mertoğlu O, Şimşek S, Başarır N (2015) Geothermal country update report of Turkey (2010-2015). World Geothermal Congress Proceedings. Melbourne, Australia, pp 19-25

28. Mertoğlu O, Şimşek S, Başarır N (2020) Geothermal energy use: projections and country update for Turkey. World Geothermal Congress Proceedings, 26 April-2 May. Reykjavik, Iceland

29. MTA (1987) Pre-feasibility study on the Dikili Bergama Geothermal Development Project in the Republic of Turkey. Technical report, MTA-JICA

30. MTA (2021) Jeotermal Elektrik Sahaları Haritası. Retrieved April 2021. https://www.mta.gov.tr/v3.0/hizmetler/jeotermal-harita

31. Muffler P, Cataldi R (1978) Methods for regional assessment of geothermal resources. Geothermics 7:53-89

32. OECD (2016) Environmental tax profile: Turkey. OECD, Centre for Tax Policy and Administration (https://www.oecd.org/tax/ tax-policy/environmental-tax-profile-turkey.pdf)

33. Özen T, Tarcan G, Gemici Ü (2005) Hydrogeochemical study of the selected thermal and mineral waters in Dikili Town, İzmir, Turkey. World geothermal congress proceedings. Antalya, Turkey, pp 24-29

34. Özen T, Tarcan G, Gemici Ü, Aksoy N (2008) Dikili-Bergama (İzmir) termal kaynaklarının hidrojeokimyasal özellikleri ve kullanım alanları. Termal ve Maden Suları Konferansı. Antalya, Turkey, pp 24-29

35. Özgür N (2020) Hydrogeological modelling of geothermal waters in Dikili (Izmir) and environs, Western Anatolia, Turkey. In: 45th Workshop on geothermal reservoir engineering proceedings. Stanford, California, pp 10-12

36. Parlaktuna M, Avşar O (2015) Evalulation of Dikili-Kaynarca Geothermal Field (NWTurkey). World geothermal congress proceedings. Melbourne, Australia, pp 10-25
37. Roba CA, Nita D, Cosma C, Codrea V, Olah S (2012) Correlations between radium and radon occurrence and hydrogeochemical features for various geothermal aquifers in Northwestern Romania. Geothermics 42:32-46. https://doi.org/10.1016/j. geothermics.2011.12.001

38. Sanyal SK, Sarmiento Z (2005) Booking geothermal energy reserves. Geotherm Resour Council Trans 29:467-474

39. Schön J (2011) Physical properties of rocks: fundamentals and principles of petrophysics, 2nd edn. Elsevier, London

40. Tabar E, Kumru M, Saç M, Ichedef M, Bolca M, Özen F (2013) Radiological and chemical monitoring of Dikili geothermal waters, Western Turkey. Radiat Phys Chem 91:89-97. https://doi.org/10. 1016/j.radphyschem.2013.04.037

41. Tian B, Kong Y, Gong Y, Ye C, Pang Z, Wang J, Zhang D (2020) An improved volumetric method of geothermal resources assessment for shallow ground combining geophysical data 145:2306-2315. https://doi.org/10.1016/j.renene.2019.08.005

42. Timur E, Sar C (2021) Depth determination from gravity data using radial amplitude spectrum: The Dikili (Izmir) geothermal area. Arab J Sci Eng. https://doi.org/10.1007/ s13369-021-05398-w

43. Turan A, Saner S, Artun E (2016) Intersecting fracture geometries in control of geothermal spring occurrences in circumferences of the Madra Mountain, Aegean Region of Turkey. Geotherm Resour Council Trans 40:611-620

44. Turan A, Artun E, Saner S (2017) Assessment of Yuntdağı hydrothermal system in Dikili-Izmir region, Western Turkey. Geotherm Resour Council Trans 41:1274-1295

45. Yılmaz Y, Genç C, Gürer F, Bozcu M, Ylmaz K, Karacık Z, Altunkaynak S, Elmas A (2000) When did the Western Anatolian grabens begin to develop? Geol Soc Lond Spec Publ 173:353-384. https://doi.org/10.1144/GSL.SP.2000.173.01.17

46. Yılmazer S, Alacalı M (2005) Distribution of hot water resources and potentials of İzmir province. World Geothermal Congress Proceedings. Antalya, Turkey, pp 24-29

47. Özürlan G, Candansayar M, Şahin M (1999) Deep resistivity structure of the Dikili-Bergama region, West Anatolia, revealed by two-dimensional inversion of vertical electrical sounding data. Geophys Prospect 54:187-197

Publisher's Note Springer Nature remains neutral with regard to jurisdictional claims in published maps and institutional affiliations. 